\title{
NOVEL KINKAKUJI: ANTARA REALITAS DAN FIKSI
}

\author{
Zaki Ainul Fadli \\ Fakultas Ilmu Budaya, Universitas Diponegoro \\ zakiaf@live.undip.ac.id
}

\begin{abstract}
(Title: Kinkakuji's novel: Between Reality and Fiction). This paper aims to reveal the similarities between historical or reality facts and fiction in Kinkakuji's novel, especially the similarity of Kinkakuji's burner profile to the main character and the timeline equation. The method used in this article is sociology of literature method and the literature study method. The results showed that there was an equation between the Kinkakuji burner profile and the main character. In addition, there are similarities in time between historical facts and the time frame found in Kinkakuji's novel.
\end{abstract}

Keywords: Kinkakuji; reality; fiction

\section{PENDAHULUAN}

Salah satu pengarang Jepang yang populer dan produktif pada Periode Modern adalah Mishima Yukio. Mishima lahir di Tokyo pada 14 Januari 1925. Mishima Yukio lahir di Tokyo pada 14 Januari 1925 dan meninggal dengan cara seppuku, yaitu bunuh diri sesuai tradisi samurai pada 25 November 1970 (usia 45 tahun). Nama aslinya ialah Hiraoka Kimitake. Ayahnya bernama Hiraoka Azusa, seorang mantan gubernur jenderal di Karafuto. Ibunya bernama Hiraoka Shizue, keturunan keluarga berpendidikan Konfusian yang mengabdi pada seorang daimyo bernama Kaga. Pada 1931 Mishima Yukio mulai bersekolah di Gakushuin, sekolahnya orangorang yang kaya. Tahun 1935 Mishima tinggal bersama kakek neneknya karena orang tuanya pindah. Pada 1937 Mishima Yukio masuk SMP dan aktif menulis di majalah sekolah Hojinkai Zasshi (Rosidi, 1989).

Pada 1944 Mishima belajar ilmu hukum di Universitas Tokyo dan kemudian bekerja di Departemen Keuangan Jepang. Delapan bulan kemudian, Mishima mengundurkan diri dari instansi itu dan mencurahkan waktunya seluruhnya untuk menulis. Atas rekomendasi guru sastranya, Shimizu Fumio, karya Mishima Yukio berjudul Hanazakari no Mori diterbitkan secara berkala di Bungei Bunka. Pada saat itulah mulai digunakan nama Mishima Yukio, nama samaran untuk mengelabuhi ayahnya dari aktivitas kepenulisannya. Pada 1946 Mishima bertemu Kawabata Yasunari, sastrawan Jepang terkenal lainnya. Kawabata lah yang merekomendasikan Mishima ke berbagai majalah yang terkenal. Karya besar Mishima pertama ialah Kamen no Kokuhaku (1949) yang berkisah tentang pengakuan homoseksualitas Mishima.

Mishima Yukio merupakan seorang yang mempunyai karakter yang kuat. Kelemahan fisiknya dan ketakutannya menjadi seorang intelektual yang tidak berguna memicunya untuk berlatih disiplin secara ketat dengan mengikuti body building, beladiri boxer, karate dan kendo. Mishima menerapkan kedisiplinan itu di dalam 
aktifitas mengarangnya. Mishima meluangkan waktu sebagian besar malamnya untuk menulis 20 novel, 33 drama, dan 80 cerpen di 16 tahun karier kepenulisannya (1944-1970).

Mishima Yukio dianggap sebagai penulis paling berbakat dan paling sukses dalam Kesusastraan Jepang Modern karena dipandang mempunyai fantasi dan kepandaian yang hebat dalam menciptakan karya sastra. Karya-karyanya banyak mendapat pujian karena Mishima mampu mengkombinasikan teknik Barat dengan tradisi dan sentuhan estetis khas Jepang ke dalam karya-karyanya. Karya-karyanya antara lain adalah Kamen no Kokuhaku (1948), Ai no Kawaki (1950), Kinjiki (1953), Shiosai (1954), Kinkakuji (1956), Kyoko no Ie (1959), Utage no Ato (1960), Gogo no Eiko(1963), Kinu to Meisatsu (1964), Mikumano Mode (1965), Sado Koshaku Fujin (1965), Yukoku (1966), Manatsu no Shi (1966), Hagakure Nyumon (1967), Waga Tomo Hittora(1968), Hojo no Umi (1964-1970), dan Taiyo to Tetsu (1970) ${ }^{1}$. Menurut Tsuruta (1991, pp. 63-64), Mishima Yukio dikenal sering menggunakan kejadian nyata sebagai bahan dasar untuk karya sastranya. Karya pertamanya dengan tipe seperti ini adalah Shinsetsu na Kikai (1949), yang didasarkan pada kasus pembunuhan di Kyoto. Karyanya yang lain adalah novel Ao no Jidai (1950) yang bercerita tentang seorang pemuda yang berusaha memulai bisnis. Karakter pemuda di novel itu merepresentasikan kondisi masyarakat Jepang yang kacau sehabis perang. Kemudian di dalam novel Kinu to Meisatsu (1964), Mishima menggunakan konflik buruh yang terjadi di sebuah perusahaan pemintalan di Hikone sebagai bahan untuk pembuatan novelnya.

\footnotetext{
${ }^{1}$ https://en.wikipedia.org/wiki/Yukio_Mishima
}

Di antara karya-karya Mishima, novel Kinkakuji adalah karya tersukses dan merupakan karya yang dijuluki sebagai Mishima's greatest masterpiece. Novel Kinkakuji memperoleh pula penghargaan sastra Yomiuri pada tahun 1957 (Hirano, 1972, pp. 7-8)

Novel Kinkakuji menceritakan petualangan pendeta gagap bernama Mizoguchi yang membakar Kinkakuji yang dikaguminya. Kisah dalam novel ini disebut mirip dengan peristiwa yang sebenarnya. Berdasarkan hal di atas tujuan artikel ini adalah untuk mengungkap persamaan antara unsur realitas dan fiksi yang terkandung dalam novel Kinkakuji karya Mishima Yukio. Ruang lingkup penelitian ini dibatasi persamaan antara profil pembakar Kinkakuji dengan tokoh utama yaitu Mizoguchi serta persamaan waktu antara fakta sejarah dengan latar waktu dalam novel Kinkakuji.

\section{METODE}

Penelitian ini merupakan penelitian dengan menggunakan pendekatan Sosiologi Sastra. Menurut Laurenson dan Swingewood (1972: 13-21), terdapat tiga perspektif berkaitan dengan sosiologi sastra, yaitu: (1) penelitian yang memandang karya sastra sebagai dokumen sosial yang di dalamnya merupakan refleksi situasi pada masa sastra tersebut diciptakan, (2) penelitian yang mengungkap sastra sebagai cermin sosial penulisnya, dan (3) penelitian yang menangkap sastra sebagai manifestasi peristiwa sejarah dan keadaan sosial budaya. Dalam penelitian ini digunakan perspektif ke-3 karena penelitian ini ingin mengungkap persamaan antara peristiwa sejarah dengan karya sastra.

Metode Studi Pustaka digunakan sebagai metode pencarian data. Dengan metode Studi Pustaka, maka sumber data 
diambil dari buku dan artikel jurnal yang berkaitan dengan tema penelitian ini.

Selain itu digunakan metode komparasi untuk membandingkan fakta sejarah dengan dua unsur struktur novel, yaitu tokoh dan latar waktunya.

\section{HASIL DAN PEMBAHASAN}

\section{Kesamaan profil Mizoguchi dan Hayashi Yoken}

Berdasarkan Kinkakuji Soosaku Nooto atau cacatan harian Mishima Yukio tentang pembuatan Novel Kinkakuji, Kinkakuji dibakar oleh seorang pendeta Kinkakuji bernama Hayashi Yoken pada 2 Juli 1950. Berdasarkan pengakuan Hayashi, dia merencanakan membakar Kinkakuji dalam 2 minggu. Sedangkan motivasinya membakar Kinkakuji adalah karena dia merasakan kecemburuan terhadap keindahan Kinkakuji yang telah menekan perasaannya. Rencananya semula dia ingin melakukan "Eiyuntekishi" (kematian heroik) di dalam Kinkakuji yang dibakarnya. Akan tetapi, ketika melihat api yang berkobar dia menjadi takut dan berlari ke arah gunung. Hayashi tidak menganggap bahwa perbuatannya membakar salah satu harta nasional bangsa Jepang sebagai sesuatu yang buruk. Dia juga tidak akan menghindar dari hukuman. Mengenai, ibunya Hayashi mengatakan sebagai berikut: "Katanya ibu saya sudah datang menjenguk saya (ke penjara), tetapi saya tidak menyayanginya, lagi pula saya hanya mempersulitkannya saja, maka saya menginginkan putusnya hubungan dengan ibu saya." Menurut Prof Uchimura, pengajar di Fakultas Kedokteran Universitas Tokyo, Hayashi termasuk orang yang shizophrenia atau memiliki kepribadian introvert yang cemas ketika berhubungan dengan orang lain. Menurutnya, pada zaman setelah perang, tipe orang seperti Hayashi sangat banyak ditemukan. Orang tipe seperti itu sangat kejam dan berhati dingin walaupun tidak mempunyai motif khusus dalam melakukan kejahatan. Umumnya penjahat mempunyai motif uang dan mempunyai rasa penyesalan, tetapi orang yang shizophrenia tidak seperti mempunyai motif dan rasa menyesal sama sekali. Hayashi masuk penjara pada 1 Januari 1952, tetapi gejala shizophrenianya bertambah dan tahun berikutnya dia menderita TBC, sehingga pada 22 Maret 1953 dia dipindahkan ke sebuah ruang perawatan di penjara lain. Akhirnya Hayashi meninggal dunia pada 7 Maret 1961 setelah penyakit TBC nya memburuk (Mishima, 2000).

Selain, itu terdapat kesamaan motif Hayashi Yoken dengan tokoh utama yaitu antipati terhadap keindahan. Hayashi Yoken, yang mengatakan bahwa motifnya adalah karena dia "antipati terhadap keindahan" (Tachibana, 2018). Kutipan berikut membuktikan bahwa tokoh Mizoguchi memiliki permasalahan dengan keindahan.

$$
\begin{aligned}
& \text { 箖しが人生で最初にぶつかった疑問 } \\
& \text { は、美ということだったと言って } \\
& \text { も過言ではない。。私には管分 } \\
& \text { の染知のところに、すでに美とい } \\
& \text { うものが存在しているという妿え } \\
& \text { に、柔満と焦燥を筧えずにはいら } \\
& \text { れなかった。美がたしかにそこに } \\
& \text { 存在しているならば、唯という } \\
& \text { 存在は、美から疎外されたものな } \\
& \text { のだ。 (Mishima, 1960: 24) }
\end{aligned}
$$


tanpa kuketahui, aku merasa gelisah dan kesal. Kalau keindahan betul ada maka hidupku sendiri adalah sesuatu yang terasing dari padanya.

美は、美的なものはもう僕にとっ

ては怨敵なんだ。（Mishima, 1960: 232)

(Keindahan, hal-hal yang indah, menurutku semuanya itu adalah musuhku)

\section{Kesamaan dalam latar waktu}

Dalam “Kinkakuji Soosaku Nooto" halaman 654 (Mishima, 2001), disebutkan bahwa Hayashi Yoken lahir pada 19 Maret 1929. Menariknya, dalam novel Kinkakuji, Mizoguchi juga lahir pada tanggal, bulan, dan tahun yang sama. Meskipun di dalam novel Kinkakuji tidak menyebutkan secara langsung kapan Mizoguchi lahir, tetapi pada halaman 215 disebutkan umur, hari dan bulan ulang tahun Mizoguchi.

$$
\begin{aligned}
& \text { 昭和二十五年三月十七日に、私 } \\
& \text { は大谷大学の予科を修了した。 } \\
& \text { 翌々日の十九日の誕生日を閲し } \\
& \text { て、満二十一歳になった。 } \\
& \text { (Mishima, 1960: 215) }
\end{aligned}
$$

Pada 17 Maret 1950, aku selesai tahap persiapan di Universitas Otani. Pada tanggal 19 hari berikutnya adalah hari ulang tahunku yang ke dua puluh satu.

Kutipan di atas menyebutkan bahwa pada 19 Maret 1950, Mizoguchi berumur 21 tahun. Maka dari kutipan tersebut dapat diketahui bahwa Mizoguchi lahir pada 19 Maret 1929.

Selain itu, terdapat pula kesamaan latar waktu antara fakta sejarah dengan novel Kinkakuji yaitu tanggal kekalahan Jepang atas sekutu yang terjadi pada 15
Agustus $1945^{2}$. Berikut kutipan di dalam novel yang mengindikasikan hal tersebut.

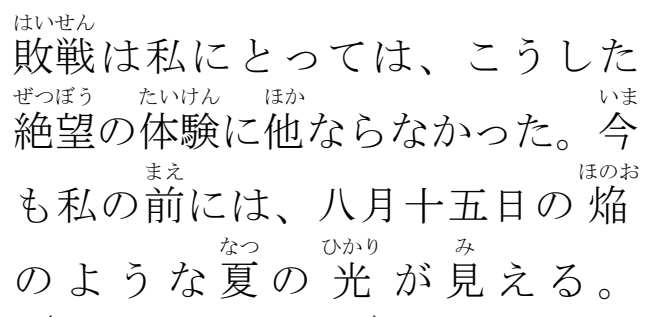

(Mishima, 1960: 69)

Kekalahan nusa dan bangsaku bagiku adalah pengalaman keputusasaan seperti itu. Bahkan kini aku masih dapat membayangkan di hadapanku cahaya musim panas yang mirip api pada hari kekalahan itu, tanggal 15 Agustus

Kutipan di atas menyebutkan bahwa pada 19 Maret 1950, Mizoguchi berumur 21 tahun. Maka dari kutipan tersebut dapat diketahui bahwa Mizoguchi lahir pada 19 Maret 1929.

\section{SIMPULAN}

Karya sastra tidak lahir dari kekosongan. Dalam proses pembuatan karya sastra, sastrawan terkadang menjadikan sebuah peristiwa sebagai inspirasi sehingga adanya kesamaan antara realitas atau fakta sejarah dengan fiksi adalah sebuah kelaziman. Kesamaan tersebut didapat dengan menganalisis unsur struktur karya sastra dan dapat dikonfirmasi dengan membandingkannya dengan fakta sejarah.

\footnotetext{
${ }^{2}$ Perang Pasifik yang menyeret Jepang ke dalam Perang Dunia II berakhir pada 15 Agustus 1945 dan perjanjian menyerahnya Jepang ditandatangani oleh wakil dari sekutu yaitu Jendral Douglas McArthur dan Jepang diwakili oleh Mamoru Shigemitsu diatas kapal USS Missouri (http://id.wikipedia.org/wiki/Perang_Pasifik)
} 
Di dalam novel Kinkakuji, terdapat kesamaan antara profil pembakar Kinkakuji yang bernama Hayashi Yoken yang membakar Kinkakuji pada tahun 2 Juli 1950 dengan tokoh utama novel Kinkakuji yaitu Mizoguchi. Selain itu, terdapat kesamaan pula antara fakta sejarah dengan latar waktu yang terdapat dalam novel Kinkakuji. Kesamaan antara fakta dan fakta sejarah tersebut memperkuat pendapat mengenai karya sastra sebagai dunia rekaan bahwa meskipun bersifat rekaan, karya sastra tetap mengacu kepada realitas dalam dunia nyata.

Penelitian ini masih dapat dikembangkan lagi karena masih banyak terdapat kemungkinan kesamaan antara fakta sejarah dengan cerita dalam novel Kinkakuji. Selain itu, dimungkinkan juga terdapat perbedaan-perbedaan di antara kedua hal tersebut untuk diteliti lebih lanjut.
Tachibana, R. (2018). The Obsession to Destroy Monuments : Mishima and Boll. Twentieth Century Literature, 39(2), 230-249. Retrieved from https://www.jstor.org/stable/441840?se $\mathrm{q}=1 \& \mathrm{cid}=$ pdfreference\#references_tab_contents

Tsuruta, K. (1991). Kinkakuji, Reality and betrayal.pdf. International Research Centre for Japanese Studies, National Institute for the Humanities. Retrieved from https://www.jstor.org/stable/25790897 $\% 0 \mathrm{~A}$

http://id.wikipedia.org/wiki/Perang_Pasifik https://en.wikipedia.org/wiki/Yukio_Mishima

\section{DAFTAR PUSTAKA}

Hirano, Y. (1972). Isolation From Life: The Early Phase Isolation Yukio Mishima. Journal of the Yokohama National University, 19, 1-13. Retrieved from http://nels.nii.ac.jp/els/110005857626.p df?id=ART0008101720\&type $=$ pdf\&la $\mathrm{ng}=$ en\&host $=$ cinii\&order_no $=\& \mathrm{ppv}$ _ty $\mathrm{pe}=0 \&$ lang_sw $=\& \mathrm{no}=1250650297 \& \mathrm{cp}$ $=\% 0 \mathrm{~A}$

Rosidi, Ajip. (1989). Mengenal Sastra dan Sastrawan Jepang. Jakarta: Erlangga

Mishima,Yukio. (2001). "Kinkakuji Soosaku Nooto" dalam Mishima Yukio Zenshuu. Tokyo : Shinchosha.

Mishima, Yukio. (1960). Kinkakuji. Tokyo: Shinchosha 